\title{
PENGARUH PENGGUNAAN MODEL PROBLEM-BASED LEARNING TERHADAP KARAKTER KREATIF DAN BERPIKIR KRITIS DALAM PEMBELAJARAN MATEMATIKA
}

\author{
Ujiati Cahyaningsih dan Anik Ghufron \\ Program Pascasarjana Universitas Negeri Yogyakarta \\ email: ujiati.dikdas13.uny@gmail.com
}

\begin{abstract}
Abstrak: Penelitian ini bertujuan untuk mengetahui pengaruh penggunaan model Problem-Based Learning terhadap karakter kreatif dan berpikir kritis siswa dalam pembelajaran matematika. Penelitian ini merupakan penelitian eksperimen semu dengan desain Pre-test-Post-test Control Group Design. Penelitian ini menggunakan dua kelompok eksperimen dan satu kelompok kontrol. Populasi penelitian ini adalah lima SD Unggulan di Purwokerto dan sampelnya adalah kelas IV di tiga SDN unggulan: kelas IV di SDN 1 Sokanegara, SDN 2 Sokanegara, dan SDN 1 Kranji. Data dianalisis menggunakan one sample t-test, uji Multivariate Analysis of Variance (MANOVA) dengan rumus $T^{2}$ Hotelling, dan dilanjutkan secara univariat dengan uji independent sample t-test. Hasil penelitian menunjukkan bahwa terdapat pengaruh yang positif dan signifikan pada penggunaan model Problem-Based Learning terhadap karakter kreatif dan berpikir kritis dalam pembelajaran matematika.
\end{abstract}

Kata Kunci: model problem-based learning, kreativitas, dan berpikir kritis

\section{THE EFFECTS OF THE IMPLEMENTATION OF THE PROBLEM-BASED LEARNING MODEL ON THE CREATIVITY AND CRITICAL THINKING SKILLS IN MATHEMATICS LEARNING}

\begin{abstract}
This research aims to determine the effects of the implementation of the Problem-Based Learning model on the students' creativity and critical thinking skills in mathematics learning. This is quasi-experimental research employing the pretest-posttest control group design. This research used two experimental groups (to which the Problem-Based Learning was implemented) and a control group (to which the conventional learning method was implemented). The research population consisted of five best state elementary schools in Purwokerto and the sample was three grade IV classes of three best schools: SDN 1 Sokanegara, SDN 2 Sokanegara, and SDN 1 Kranji established randomly. The data were analyzed using the one-sample t-test, the test of Multivariate Analysis of Variance (MANOVA) using the $\mathrm{T}^{2}$ Hotelling formula and then followed univariately by the independent sample t-test. The findings indicated that there were significant and positive effects of the implementation of the Problem-Based Learning model on the creativity and the critical thinking skills in mathematics learning.
\end{abstract}

Keywords: the problem-based learning model, creativity, critical thinking

\section{PENDAHULUAN}

Tujuan pembelajaran berdasarkan Undang-Undang Sistem Pendidikan Nasional Nomor 20 Tahun 2003 adalah untuk mengembangkan potensi siswa menjadi insan yang kreatif, inovatif, mandiri, demokratis, dan bertanggung jawab. Oleh karena itu, guru dan pihak sekolah perlu menciptakan pembelajaran yang mendukung terbentuk- nya potensi sesuai dengan tujuan undangundang.

Salah satu dari tujuan pendidikan nasional adalah mewujudkan siswa yang kreatif. Pribadi yang kreatif harus dibentuk sejak dini, termasuk saat siswa menempuh jenjang pendidikan. Hal ini, karena kreativitas merupakan proses berpikir seseorang untuk menghasilkan sesuatu yang baru dari sesuatu yang sudah ada sebelumnya 
dan melahirkan sesuatu yang unik sesuai dengan idenya.

Pada kenyataannya, siswa saat di sekolah lebih dituntut untuk menyelesaikan soal matematika dengan jawaban yang benar dan cara yang sesuai dengan contoh yang guru berikan. Hal ini tentu saja membatasi kreativitas siswa dalam menyelesaikan soal matematika dengan memberikan alternatif-alternatif cara yang meningkatkan kreativitasnya. Tumbuhnya kreativitas anak dapat di dukung dengan kemampuan berpikir kritis pada anak tersebut.

Berpikir kritis adalah interpretasi dan evaluasi yang terampil dan aktif terhadap observasi dan komunikasi, informasi dan argumentasi. Berpikir kritis akan membantu siswa memiliki pemikiran mengenai halhal yang dapat dipercaya atau yang tidak dapat dipercaya. Masalah lain yang terjadi di sekolah adalah saat di sekolah siswa lebih banyak menerima begitu saja materi yang diberikan oleh guru. Hal ini senada dengan pendapat Widyastuti \& Pujiastuti (2014:184) yang menyatakan bahwa kemampuan berpikir logis merupakan kemampuan berpikir siswa untuk menarik kesimpulan yang sah menurut aturan logika. Jadi, kemampuan berpikir kritis atau logis ini bukan merupakan hasil transfer ilmu dari seseorang ke orang lain dalam hal ini guru ke siswa, akan tetapi dibentuk sendiri oleh siswa melalui pengalaman nyata dengan mengaitkan pengetahuan yang telah dimilikinya.

Kreativitas dan berpikir kritis menjadi fokus pengamatan. Oleh karena itu, diperlukan suatu model yang sesuai untuk meningkatkan kreativitas dan berpikir kritis siswa yaitu model Problem-Based Learning (PBL). Joyce, Weil, \& Calhoun (2009: 30) menyatakan bahwa model pembelajaran merupakan gambaran suatu lingkungan pembelajaran yang juga meliputi perilaku guru saat model tersebut diterapkan. Model pembelajaran adalah pedoman guru dalam mengorganisasikan pengalaman belajar siswa untuk mencapai tujuan belajar yang konseptual, prosedural, dan sistematis. Terdapat beberapa model pembelajaran menurut Hamzah \& Muhlisrarini (2014: 156-179) di antaranya model kolaboratif, model kuantum, model kooperatif, model tematik, model sosial, model perilaku, model behaviourisme, model kognitivisme, dan model konstruktivisme.

Model pembelajaran kolaboratif adalah apabila dua orang atau lebih bekerja sama memecahkan masalah bersama untuk mencapai tujuan tertentu. Dalam model pembelajaran kuantum siswa belajar secara individual yang ia dapat pindah kepada modul berikutnya bila telah memahami secara keilmuan dan praktiknya. Model pembelajaran kooperatif siswa bekerja dalam satu kelompok yang heterogen dan terdiri dari 4-6 siswa yang saling bekerja sama untuk menyelesaikan tugas kelompok. Model ini memiliki beberapa tipe di antaranya STAD, Jigsaw, Pembelajaran Berbasis Masalah, GI, Talking Stick, Role Playing, NHT, dan CIRC. Kegiatan model pembelajaran tematik dirancang berawal dari ide pokok atau tema dengan melibatkan beberapa bidang studi yang berkaitan dengan tema, guru berupaya melakukan pendekatan konteks dengan penyajian secara utuh menyeluruh bukan parsial. Model pembelajaran sosial berorientasi pada kondisi sosial atau lingkungan sosial yang menjadi tempat interaksi antarindividu atau antarkelompok. Model pembelajaran perilaku berarti proses pembelajaran yang menekankan dan berorientasi perubahan sikap motorik yang terjadi pada anak didik. Prinsip utama model behaviorisme adalah stimulus, respons, dan penguatan. Model pembelajaran kognitivisme, belajar adalah suatu rangkai- 
an fase langkah-langkah kognitif: pengodean, penyimpanan, perolehan kembali, dan pemindahan informasi.

Problem-Based Learning (PBL) adalah suatu model pembelajaran yang diawali dengan pemberian masalah kepada siswa, selanjutnya siswa menyelesaikan masalah tersebut untuk menemukan pengetahuan baru, dan disini siswa dituntut untuk lebih aktif dalam proses belajar mengajar. Anindyta dan Suwarjo (2014:212) model PBL sebagai model pembelajaran yang inovatif yang menekankan pada kegiatan pembelajaran yang berpusat pada siswa dengan masalah sebagai acuan dalam proses pembelajaranya. Savin-Baden (2007:10) menyatakan:

"Problem-based learning is thus an approach to learning that is characterized by flexibility and diversity in the sense that it can be implemented in a variety of ways in and across different subjects and disciplines in diverse contexts. As such it can therefore look very different to different people at different moments in time depending on the staff and students involved in the programmes utilizing it."

Menurut Sanjaya (2006:220) kelebihan dari model pembelajaran Problem Based Learning (PBL) adalah (1) mengembangkan jawaban yang bermakna bagi suatu masalah yang akan membawa siswa mampu menuju pemahaman lebih dalam mengenai suatu materi; (2) memberikan tantangan pada siswa sehingga siswa bisa memperoleh kepuasan dengan menemukan pengetahuan baru bagi dirinya sendiri; (3) membuat siswa selalu aktif dalam pembelajaran; (4) dapat mengembangkan keterampilan berpikir kritis setiap siswa, serta kemampuannya beradaptasi untuk belajar dengan situasi yang baru; (5) menantang kemampuan siswa serta memberikan kepuasan untuk menemukan pengetahuan baru bagi siswa; (6) dapat meningkatkan aktivitas belajar siswa; dan (7) dapat membantu siswa bagaimana mentansfer pengetahuannya untuk memahami masalah dalam kehidupan nyata.

Secara sederhana dalam PBL guru berperan memberikan suatu masalah kepada para siswa. Kemudian, siswa dituntut untuk dapat menyelesaikan masalah tersebut dengan cara mereka sendiri dan guru hanya memfasilitasi agar siswa dapat mengembangkan pikiran mereka untuk memperoleh pengetahuan dalam memecahkan masalah yang diberikan. Siswa secara aktif membangun pengetahuan yang dibutuhkan dari masalah yang diberikan. Peran aktif siswa dalam proses belajar menunjukkan bahwa PBL bukan proses mentransfer ilmu dari guru ke siswa tetapi peran guru disini sebagai fasilitator yang menyediakan masalah dan mediator yang dibutuhkan oleh siswa untuk membangun pengetahuannya sendiri. Salah satu alternatif model pembelajaran yang memungkinkan dikembangkannya keterampilan berpikir siswa (penalaran, komunikasi, dan koneksi) dalam memecahkan masalah (Rusman, 2010: 229). Jadi, PBL adalah model pembelajaran yang berpusat pada siswa yang mengelaborasikan pemecahan masalah dengan pengalaman sehari-hari.

Model PBL yang dikemukakan oleh Cheong (2008:50): "Students solve problems that serve as a stimulus to learning in small groups guided by a tutor whose role is to facilitate the learning process by asking questions and monitoring the process". Dewey menyatakan bahwa sekolah seharusnya menjadi laboratorium untuk pengatasan masalah kehidupan nyata bagi siswa. Perspektif kognitif oleh Piaget dinyatakan bahwa siswa dengan umur berapa pun terlibat secara aktif dalam proses mendapatkan informasi dan mengonstruksikan pengetahuannnya 
sendiri. Discovery learning menekankan pentingnya membantu siswa untuk memahami ide-ide dan konsep inti dari disiplin ilmu, kebutuhan akan keterlibatan aktif siswa dalam proses belajar dan keyakinan bahwa pembelajaran sejati terjadi melalui proses penemuan pribadi. Bruner juga mengajukan konsep scaffolding, yaitu suatu proses untuk membantu siswa menuntaskan masalah tertentu melampaui kapasitas perkembangannnya melalui bantuan guru, teman sebaya atau orang lain yang memiliki kemampuan lebih (Cheong, 2008).

Karakteristik PBL yang dikemukakan oleh Zabit(2010:20), “The main characteristics of PBL: (1) student centred; (2) problem-based; (3) problem solving; (4) self-directed; (5) reiterative; (6) collaborative; (7) self reflecting; (8) self-monitoring; and (9) authentic". Pernyataan tersebut mengandung arti bahwa karakteristik PBL yaitu: (1) berpusat pada siswa; (2) berbasis pada masalah; (3) penyelesaian masalah; (4) menentukan sendiri caranya untuk menyelesaikan masalah; (5) reitrative yaitu setelah siswa dapat informasi, siswa membawa informasi itu kembali kepermasalahan yang ada dan mereka baru menyelesaikannya; (6) kolaboratif; (7) self reflecting: merefleksi sendiri; (8) self monitoring: mengevaluasi lagi, memonitor lagi dari awal, untuk mengetahui perkembangannya apa dan apa yang diperoleh; dan (9) autentik. Oleh karena itu, PBL memiliki karakteristik bahwa pembelajaran berpusat pada siswa, pembelajarannya berbasis pada masalah yang masalahnya autentik dan di sini guru bertindak sebagai fasilitator, dan dari pembelajaran tersebut siswa nantinya dapat menemukan sendiri cara untuk memecahkan masalah.

Berdasarkan karakteristik tersebut, PBL mempunyai sintak. Menurut Tan (2009: 9), proses pembelajaran PBL terdiri atas beberapa langkah, yaitu: (1) menemukan ma- salah; (2) menganalisis masalah; (3) menemukan dan melaporkan; (4) mempresentasikan solusi dan merefleksi; dan (5) melihat kembali, mengevaluasi dan belajar secara mandiri. Setiap siswa dituntut untuk mandiri tetapi dalam PBL siswa belajar dalam bentuk kelompok untuk memahami masalah yang dihadapinya. Langkah PBL yang dikemukakan oleh Cozzola (2008:1), yaitu: (1) pupils are given a problem; (2) they discuss the problem and/or work on the problem in small groups, collecting information useful to solve the problem; (3) all the pupils gather together to compare findings and/or discuss conclusions; new problems could arise from this discussion, in this case; (4) pupils go back to work on the new problems, and the cycle starts again.

Pada fase pertama siswa membutuhkan pemahaman yang jelas tentang maksud dan tujuan pembelajaran dengan model PBL sehingga pembelajaran bukan hanya sekedar untuk memperoleh informasi baru tetapi untuk menyelidiki masalah yang dihadapi sehingga siswa bertanggung jawab atas pencapaian tujuan pembelajaran secara mandiri. Pada fase kedua guru mengatur siswa untuk melaksanakan kegiatan pembelajaran berdasarkan masalah. Pembelajaran dengan model PBL menghendaki siswa berkolaborasi untuk menyelidiki masalah bersama.

Guru membantu siswa untuk mengembangkan keterampilan sosialnya melalui kerja sama. Agar dapat belajar bersama, siswa hendaknya dikelompokkan dalam kelompok-kelompok kecil sehingga mudah dikontrol dan tidak membosankan. Pengelompokan siswa diatur berdasarkan berbagai kepentingan, misalnya guru membagi kelompok-kelompok siswa berdasarkan gender, etnik, dan tingkat kemampuan. Jika perbedaan-perbedaan tidak berpengaruh, guru dapat mengelompokkan siswa 
berdasarkan minat siswa yang sama atau kelompok teman akrab atau dekat.

Setelah pembentukan kelompok, siswa akan secara bersama-sama menyusun rencana. Kegiatan penyusunan rencana perlu memperhatikan waktu yang disediakan untuk subtopik khusus, menyelidiki tugas-tugas dan batas waktu untuk tugastugas tersebut. Pada kegiatan selanjutnya berdasarkan rencana yang disusun bersama, guru membimbing siswa secara individual atau kelompok-kelompok kecil. Kegiatan investigasi dilaksanakan secara mandiri, kelompok atau berpasangan. Kegiatan investigasi meliputi kegiatan mengumpulkan data dan melakukan eksperimen jika perlu, menyusun hipotesis, menyelesaikan masalah, dan menyiapkan alternatif penyelesaian.

Selanjutnya, siswa dituntut untuk menghasilkan produk berupa solusi-solusi dan mempresentasikannya. Produk yang dihasilkan oleh siswa berupa laporan, tabel, diagram, dan bentuk-bentuk yang bersifat fisik. Kegiatan pada fase ini akan dilanjutkan dengan kegiatan mempresentasikan hasil karya. Pada tahap ini siswa diharapkan dapat mengomunikasikan gagasangagasan dengan simbol, tabel, atau diagram. Tahap terakhir dari kegiatan pembelajaran dengan model PBL adalah aktivitas yang ditujukan untuk membantu siswa membuat analisis dan mengevaluasi hasil pekerjaannya sehingga dapat menemukan pengetahuan yang merupakan tujuan pembelajaran.

Jika siswa belum terbiasa dengan pembelajaran menggunakan model PBL guru dapat membantu siswa dengan memberikan beberapa pertanyaan. Dalam kegiatan pembelajaran matematika siswa dapat dibantu dengan memberikan lembar kerja yang berisi konteks atau masalah kon- tekstual yang mengarahkan siswa untuk memahami materi yang akan diajarkan.

Manfaat yang didapatkan dengan penggunaan PBL menurut Bell (2010:39) bahwa siswa dapat menyelesaikan masalah kehidupan sehari-hari dengan merancang penemuannya sendiri, merencanakan pembelajarannya sendiri, mengatur risetnya, dan mengimplementasikan pada beberapa strategi pembelajaran.

Berpikir tidak dapat dilepaskan dari aktivitas manusia, karena berpikir merupakan ciri yang membedakan manusia dengan makhluk lainnya. Ketika kemampuan berpikir itu terus dilatih, dapat dikembangkan pula kemampuan berpikir tingkat tinggi seperti kemampuan berpikir kritis dan berpikir kreatif.

Istilah kreativitas dan berpikir kreatif seringkali dihubungkan dalam setiap pembahasan baik dalam artikel maupun bukubuku teks. Kreativitas seseorang menunjukkan kemampuan berpikir kreatif orang tersebut. Kedua istilah tersebut pada dasarnya berhubungan secara konseptual, namun keduanya tidak sama persis. Budiharti \& Jailani (2014:28) menyatakan bahwa kreativitas akan tumbuh dan berkembang dengan baik jika lingkungan keluarga, masyarakat, dan lingkungan sekitar mendukung siswa mengeksplorasi kreativitasnya. Johnson (2010:214) menyatakan bahwa berpikir kreatif adalah sebuah kebiasaan dari pikiran yang dilatih dengan memerhatikan intuisi, menghidupkan imajinasi, mengungkapkan kemungkinan-kemungkinan baru, membuka sudut pandang yang menakjubkan, dan membangkitkan ide-ide yang tidak terduga.

Menurut Guilford (Alghafri \& Ismail, 2014: 518) "identified four central components of creative thinking skills (divergent thinking) that include: fluency, flexibility, originality and elaboration". Pernyataan tersebut mengan- 
dung makna bahwa komponen utama dari keterampilan berpikir kreatif (berpikir divergen) yang termasuk di dalamnya dapat diidentifikasikan menjadi empat, yaitu: (1) kelancaran; (2) keluwesan; (3) keaslian; dan (4) keterperincian. Selanjutnya, untuk mengukur kemampuan berpikir kreatif ini digunakan tes uraian untuk memperoleh data kemampuan berpikir kreatif sebelum dan setelah pembelajaran seperti terlihat pada Tabel 1.

Berpikir kritis merupakan kemampuan menggunakan logika. Lau (2011:1) menyatakan, "Critical thinking is thinking clearly and rationally. It involves thinking precisely and systematically, and following the rules of logic and scientific reasoning, among other things". Pernyataan tersebut mengandung arti bahwa berpikir kritis adalah berpikir jernih dan rasional. Ini melibatkan berpikir tepat dan sistematis, dan mengikuti aturan logika dan penalaran ilmiah. Berpikir kritis melibatkan penggunaan standar, seperti ke- jelasan, akurasi, relevansi, dan kelengkapan. Hal ini memerlukan bukti, mengevaluasi, mempertimbangkan alternatif, dan secara adil dan akurat menyajikan pandangan yang bertentangan.

Nitko \& Brookhart (2007:222) menyebutkan bahwa strategi penilaian kemampuan berpikir kritis terdiri dari 5 kategori yang menjadi 12 indikator sebagai berikut. Pertama, melakukan klarifikasi dasar dengan fokus pada pertanyaan, menganalisis argumen, meminta dan menjawab pertanyaan klarifikasi dan tantangan. Kedua, menilai dukungan dasar informasi dengan menilai kredibilitas informasi, dan membuat dan menilai observasi. Ketiga, menarik kesimpulan dengan melihat dan menilai deduksi, membuat dan menilai induksi, dan membuat dan menilai keputusan. Keempat, melakukan klarifikasi tingkat lanjut dengan mengidentifikasi istilah dan menilai istilah dan mengidentifikasi asumsi.

\section{Tabel 1. Aspek Kemampuan Berpikir Kreatif}

\begin{tabular}{cl}
\hline Aspek & Indikator \\
KBK & KBK \\
\hline 1. Fluency (kelancaran) & - Menjawab dengan sejumlah jawaban jika ada pertanyaan \\
& - Mempunyai banyak gagasan mengenai suatu masalah \\
& - Menyelesaikan masalah yang penyelesaiannya sederhana \\
2. Flexibility (keluwesan) & - Memberikan bermacam-macam penafsiran terhadap suatu gambar, \\
& cerita, atau masalah \\
& - Jika diberi suatu masalah dapat menggunakan beberapa cara dalam \\
& menyelesaikan masalah \\
3. Originality (keaslian) & - Menggolongkan hal-hal menurut pembagian (kategori) yang berbeda \\
& - Setelah diberi suatu masalah dapat menjawab masalah dengan \\
& menggunakan bahasa, cara atau idenya sendiri \\
4. Elaboration & Mencari arti yang lebih mendalam terhadap jawaban atau pemecahan \\
(keterperincian) & masalah \\
& - Mengembangkan atau memperkaya gagasan orang lain \\
& - Memberikan jawaban secara terperinci, runtut dan koheren terhadap \\
& prosedur matematis, jawaban, atau situasi matematis tertentu \\
\hline
\end{tabular}


Kelima, menerapkan strategi dan taktik dalam memecahkan masalah dengan memutuskan suatu tindakan, dan berintaraksi dengan orang lain. Pada penelitian ini, keterampilan berpikir kritis yang diteliti meliputi: (1) fokus pada permasalahan; (2) menuliskan kesalahan dari penyelesaian suatu masalah; (3) memperbaiki penyelesaian masalahyang disajikan; (4) memutuskan suatu tindakan dalam menerapkan strategi dan taktik dalam menyelesaikan masalah; dan (5) menuliskan kesimpulan dari penyelesaian masalah.

Dalam mewujudkan kriteria-kriteria tersebut, guru dan pihak sekolah dituntut menciptakan pembelajaran kreatif, inovatif dan berkualitas untuk mengatasi masalah lemahnya proses pembelajaran. Proses pembelajaran melibatkan guru, orang tua dan masyarakat. Berkaitan dengan proses pembelajaran yang melibatkan guru di sekolah, pembelajaran harus dilakukan secara optimal sehingga sekolah menjadi salah satu komponen yang terlibat dalam peningkatan kedua aspek ini. Sekolah berpenampilan unggul selalu menekankan pada kemandirian dan kreativitas sekolah yang memfokuskan pada perbaikan proses pembelajaran.

\section{METODE}

Subjek penelitian ini adalah siswa kelas IV pada SDN 1 Sokanegara, SDN 2 Sokanegara, dan SDN 1 Kranji Tahun Ajaran 2014/2015. Penelitian ini merupakan eksperimen semu dengan desain penelitian pretest-posttest nonequivalen control group design. Pada desain ini, terdapat tiga kelompok, yaitu dua kelompok eksperimen yang menerapkan model PBL dan satu kelompok kontrol yang menerapkan pembelajaran konvensional. Adapun teknik pengumpulan data yang digunakan dalam penelitian ini adalah mengumpulkan data sebelum diberikan perlakuan, yaitu dengan memberikan pretest kreativitas dan berpikir kritis siswa dalam pembelajaran matematika; melakukan tindakan penelitian dengan memberikan perlakuan model PBL pada kelas eksperimen; dan mengumpulkan data setelah diberikan perlakuan pada kelas eksperimen dan kontrol dengan memberikan posttest kreativitas dan berpikir kritis siswa dalam pembelajaran matematika. Reliabilitas instrumen dapat dilihat pada Tabel 2.

\section{Tabel 2. Nilai Alpha Cronbach}

\begin{tabular}{cc}
\hline Instrumen & Nilai a \\
\hline Kreativitas & 0,816 \\
Berpikir Kritis & 0,712 \\
\hline
\end{tabular}

Teknik analisis data yang digunakan dalam penelitian ini adalah analisis deskriptif dan inferensial. Analisis deskriptif untuk mendeskripsikan keadaan sebelum dan sesudah diberikan perlakuan pada ketiga kelas ditinjau dari masing-masing variabel terikatnya. Analisis inferensial dilakukan untuk mengambil kesimpulan berdasarkan data yang telah diperoleh selama proses penelitian berlangsung. Analisis inferensial ini terdiri atas uji pengaruh dan uji komparasi.

Sebelum dilakuan analisis, dibuat ketentuan kriteria pencapaian ketuntasan belajar siswa untuk kreativitas dan berpikir kritis siswa dalam pembelajaran matematika. Siswa dikatakan tuntas belajar ketika skor yang diperoleh siswa dinilai berdasarkan pedoman penskoran yang telah disesuaikan dengan indikator. Total skor yang diperoleh kemudian dikonversi pada skala 100. Siswa dikatakan tuntas apabila nilainya lebih dari 65.

Data-data yang diperoleh selama penelitian berlangsung harus memenuhi uji asumsi terlebih dahulu sebelum melalui 
proses analisis. Uji asumsi yang harus dipenuhi adalah uji normalitas dengan menggunakan kriteria Chi square (Johnson, 2002: 182-183) yaitu nilai $d_{i}{ }^{2}<x^{2} p(0,5)$ mendekati $50 \%$, dapat dikatakan bahwa data tersebut berdistribusi normal. Selain itu, homogenitas kelompok diuji dengan menggunakan uji Box-M. Jika nilai signifikansi yang diperoleh lebih dari 0,05, maka matriks kovarians populasi tersebut homogen.

Setelah melewati proses uji asumsi, dilanjutkan dengan one sample t-test untuk menganalisis pengaruh model PBL dari masing-masing variabel terikatnya. Sementara itu, analisis perbedaan pengaruh antara model PBL dengan pembelajaran konvensional dilakukan dengan uji Multivariate Analysis of Variance (MANOVA) $T^{2}$ Hotelling. Taraf signifikansi yang digunakan pada uji pengaruh adalah 0,05. Uji univariat dilakukan dengan menggunakan independent sample $t$ test dengan taraf signifikansi 0,01. Uji ini digunakan untuk melihat apakah model PBL lebih berpengaruh dibandingkan dengan pembelajaran konvensional.

\section{HASIL DAN PEMBAHASAN Hasil Penelitian}

Hasil penelitian ini terdiri atas hasil uji pengaruh dan uji komparasi pengaruh antara kelompok eksperimen yang menggunakan model PBL dan kelompok kontrol yang menggunakan pembelajaran konvensional. Hasil uji pengaruh dengan menggunakan one sample t-test akan disajikan pada Tabel 3.

Tabel 3. Hasil Uji Pengaruh Model PBL

\begin{tabular}{ccccc}
\hline Kelas & Variabel & $\overline{\boldsymbol{x}}$ & $\boldsymbol{t}_{\text {hitung }}$ & Sig \\
\hline \multirow{2}{*}{ Eks 1 } & $\mathrm{K}$ & 75,31 & 18,802 & 0,000 \\
\cline { 2 - 5 } & $\mathrm{BK}$ & 85,45 & 24,598 & 0,000 \\
\hline \multirow{2}{*}{ Eks 2 } & $\mathrm{K}$ & 82,02 & 14,106 & 0,000 \\
\cline { 2 - 5 } & $\mathrm{BK}$ & 81,98 & 18,198 & 0,000 \\
\hline
\end{tabular}

Berdasarkan hasil perhitungan pada Tabel 2 terlihat bahwa untuk variabel $\mathrm{K}$ dan BK memiliki taraf signifikansi lebih kecil dari 0,05. Hal ini berarti model PBL berpengaruh terhadap kreativitas dan berpikir kritis siswa. Setelah melakukan uji pengaruh, dilanjutkan dengan menguji perbedaan pengaruh antara model PBL dengan pembelajaran konvensional menggunakan uji multivariat $T^{2}$ Hotelling dengan bantuan SPSS 20,0 for Windows. Hasil perhitungan tersebut menunjukkan bahwa taraf signifikansi yang diperoleh 0,000 0 0,05. Ini menunjukkan bahwa terdapat perbedaan pengaruh antara kelas eksperimen dengan kelas kontrol terhadap kreativitas dan berpikir kritis siswa dalam pembelajaran matematika. Karena berdasarkan hasil perhitungan tersebut menyatakan terdapat perbedaan pengaruh. Untuk dapat menyimpulkan mana yang lebih berpengaruh terlebih dahulu akan di uji kembali dengan menggunakan uji independent sample t-test.

\section{Tabel 4. Hasil Independet Sample t-test}

\begin{tabular}{ccc}
\hline Variabel & $\mathbf{T}$ & Signifikansi \\
\hline Kreativitas & 17,483 & 0,000 \\
\hline Berpikir Kritis & 17,458 & 0,000 \\
\hline
\end{tabular}

Berdasarkan hasil perhitungan pada tabel 4 terlihat bahwa nilai signifikansi dari masing-masing variabel terikatnya adalah lebih kecil 0,01. Dengan demikian, dapat disimpulkan bahwa pembelajaran matematika dengan model PBL lebih berpengaruh daripada pembelajaran konvensional terhadap kreativitas dan berpikir kritis siswa dalam pembelajaran matematika. Hal ini sesuai dengan hasil analisis deskriptif yang menunjukkan bahwa rata-rata pada kelas eksperimen lebih besar dari pada kelas kontrol sehingga rata-rata tersebut memberikan kontribusi maksimal pada kelas eksperimen. 
Hasil analisis deskriptif juga menunjukkan bahwa pembelajaran matematika dengan model PBL berpengaruh positif terhadap kreativitas dan berpikir kritis siswa dalam pembelajaran matematika. Hal ini terlihat dari kondisi awal siswa sebelum dan sesudah diberikan perlakuan. Pada kondisi awal di kelas eksperimen tidak ada satu pun siswa yang mencapai ketuntasan untuk kreativitas dan berpikir kritis, sehingga perlakuan dilakukan untuk melihat seberapa besar kemajuan yang dibuat oleh suatu model pembelajaran. Hasil analisis deskriptif dari ketiga kelas dapat dilihat pada Tabel 5.

Tabel 5. Rerata Kelas Eksperimen dan Kelas Kontrol

\begin{tabular}{ccccc}
\hline & \multicolumn{2}{c}{ Deskriptif } & \multicolumn{1}{c}{ K } & BK \\
\hline \multirow{3}{*}{ E } & \multirow{2}{*}{ PBL A } & Pre & 42,60 & 39,58 \\
\cline { 2 - 5 } & & Post & 82,02 & 85,45 \\
\cline { 2 - 4 } & \multirow{2}{*}{ PBL B } & Pre & 38,44 & 43,13 \\
\cline { 3 - 5 } & & Post & 75,31 & 81,98 \\
\hline \multirow{2}{*}{ K } & \multirow{2}{*}{ Konv } & Pre & 40,21 & 37,75 \\
\cline { 3 - 5 } & & Post & 56,15 & 58,88 \\
\hline
\end{tabular}

\section{Pembahasan}

Hasil uji one sample t-test menunjukkan bahwa model PBL berpengaruh terhadap kreativitas siswa. Hal ini menunjukkan bahwa peningkatan keterampilan berpikir kreatif siswa pada kelas yang mendapatkan pembelajaran berbasis masalah (PBM) lebih besar dari kelas yang mendapatkan pembelajaran tradisional. Begitu juga pada peningkatan pada tiap aspeknya, yaitu fluency, flexibility, originality, dan elaboration. Selain itu, hasil ini sesuai pula dengan hasil penelitian yang dilakukan oleh Iakovos (2011) bahwa "problem-based learning (PBL) can foster creative thinking. It allows teachers to make useful additions to their traditional teaching, such as "problem-solving activities, critical-thinking exercises, collaborative learning, and independent study, and allows them to put these into context and give them meaning" maknanya problem-based learning (PBL) dapat meningkatkan berpikir kreatif. Hal ini memungkinkan guru untuk membuat penambahan yang berguna dalam pembelajaran tradisional mereka, seperti "kegiatan pemecahan masalah, berpikir kritis, pembelajaran kolaboratif, dan belajar mandiri, dan menempatkan ini ke dalam konteks pembelajaran".

Berdasarkan hasil analisis deskriptif, terlihat pula bahwa rerata siswa sebelum dan sesudah diberikan perlakuan mengalami peningkatan sehingga model PBL dapat membantu siswa untuk meningkatkan berpikir kritis siswa. Hal ini sesuai dengan penelitian yang dilakukan oleh Abdur Rahman As'ari (2014) bahwa "Problem Based Learning to promote critical thinking skill" maknanya PBL untuk meningkatkan kemampuan berpikir kritis. Selain itu, hasil ini sesuai pula dengan hasil penelitian yang dilakukan oleh Ahlam El-Shaer dan Hala Gaber (2014) bahwa "there were statistical significant improvements in students critical thinking post PBL than pre intervention" maknanya bahwa terdapat hasil statistik yang signifikan pada peningkatan kemampuan berpikir kritis siswa yang menggunakan PBL dengan yang tidak menggunakan PBL.

Berdasarkan hasil pengamatan guru selama proses penelitian, terdapat beberapa masalah yang dihadapi oleh siswa di antaranya siswa mengalami kesulitan ketika menentukan strategi atau cara apa yang akan digunakan untuk menyelesaikan masalah sehingga sebagian siswa memilih untuk menggunakan cara sesuai dengan tingkat berpikir siswa apabila diberikan suatu permasalahan dalam bentuk soal. 
Hasil pengamatan tersebut didukung pula dengan hasil wawancara peneliti dengan guru matematika yang mengampu ketiga kelas ini, bahwa sebagian siswa masih lemah dalam operasi hitung bilangan bulat seperti penjumlahan, pengurangan, pembagian dan perkalian. Materi ini merupakan titik pangkal dari matematika yang harusnya sudah dikuasai oleh siswa sejak di jenjang Sekolah Dasar (SD). Hal ini bukan tidak mungkin untuk diperbaiki namun butuh proses yang tidak sebentar, dimana setiap pagi siswa berbaris dan diperbolehkan masuk ke kelas bila siswa mampu menjawab pertanyaan dari guru yang berupa operasi hitung bilangan. Hal ini yang guru lakukan setiap harinya.

Pembelajaran matematika dengan model PBL memfasilitasi siswa untuk mengontruksi pengetahuan siswa sesuai dengan tahap perkembangan kognitif dari masingmasing siswa. Siswa diberikan kebebasan untuk menghasilkan jawaban sendiri sesuai dengan logika berpikir siswa sehingga terdapat beragam cara yang dapat dihasilkan siswa melalui proses ini. Model ini juga memberikan dampak positif terhadap siswa dalam pembelajaran matematika di antaranya adalah siswa terlihat lebih aktif, bersemangat, dan antusias ketika memulai pembelajaran matematika. Siswa juga berani mengemukakan pendapat dan menjawab pertanyaan guru dengan menggunakan berbagai variasi jawaban yang dipikirkan lalu mempresentasikannya di depan kelas.

Hasil analisis data pretest dengan menggunakan Manova menunjukkan bahwa tidak ada perbedaan kemampuan awal siswa antara kelas eksperimen dan kelas kontrol terhadap kreativitas dan berpikir kritis siswa dalam pembelajaran matematika. Ini berarti sebelum diberikan perlakuan pada kelas eksperimen ataupun kelas kontrol ditinjau dari kedua variabel terikat tersebut tidak berbeda kemampuan awalnya, sehingga ketiga kelas berada pada tingkatan yang sama sebelum perlakuan. Namun, setelah diberikan perlakuan, tampak adanya perbedaan antarketiga kelas terhadap masing-masing variabel terikatnya.

Hasil analisis menunjukkan bahwa terdapat perbedaaan pengaruh antara kelas eksperimen dan kelas kontrol terhadap kreativitas dan berpikir kritis siswa dalam pembelajaran matematika. Dikarenakan terdapat perbedaan pengaruh antarketiga kelompok, maka dilakukan uji univariat independent sample t-test untuk mengetahui rerata variabel kelompok mana yang memberikan kontribusi maksimal terhadap perbedaan pengaruh antara ketiga kelompok. Adapun hasil uji lanjut yang telah dilakukan dengan uji independent sample t-test dapat dilihat pada Tabel 6 .

Tabel 6. Hasil Independent Sample t-Test

\begin{tabular}{ccc}
\hline Variabel & T & Signifikansi \\
\hline $\mathrm{K}$ & 17,483 & 0,000 \\
\hline $\mathrm{BK}$ & 17,458 & 0,000 \\
\hline
\end{tabular}

Berdasarkan hasil analisis tersebut, terlihat bahwa taraf signifikansi dari kedua variabel terikatnya kurang dari 0,01 . Hal ini menunjukkan bahwa pembelajaran matematika dengan model PBL lebih berpengaruh daripada pembelajaran konvensional terhadap kreativitas dan berpikir kritis siswa. Hasil ini didukung pula oleh hasil analisis deskriptif yang menunjukkan bahwa rerata kelompok eksperimen lebih tinggi dari kelompok kontrol terhadap kreativitas dan berpikir kritis siswa.

\section{PENUTUP}

\section{Simpulan}

Berdasarkan hasil penelitian dan pembahasan tersebut, dapat disimpulkan bah- 
wa model PBL berpengaruh terhadap karakter kreatif siswa dan model PBL berpengaruh terhadap karakter berpikir kritis siswa. Selain itu, terdapat perbedaan pengaruh antara kelas eksperimen dan kelas kontrol dalam kedua karakter tersebut, sehingga menyebabkan pembelajaran matematika dengan model PBL lebih berpengaruh dari pembelajaran konvensional terhadap kreativitas dan berpikir kritis siswa.

\section{Saran}

Sebagai tindak lanjut dari hasil penelitian ini dapat dikemukakan beberapa saran bagi peneliti lain yang ingin melakukan penelitian dengan model PBL untuk meneliti hal-hal yang berkaitan dengan materi dan aspek afektif dan kognitif yang benar-benar menjadi masalah di sekolah atau kelas yang akan dijadikan tempat penelitian. Hal ini bertujuan agar upaya perbaikan yang dilakukan benar-benar memberikan kontribusi positif bagi siswa, guru, dan tempat sekolah tempat penelitian berlangsung.

\section{UCAPAN TERIMA KASIH}

Penulis mengucapkan terima kasih yang sebesar-besarnya kepada Dewan Redaksi Jurnal Pendidikan Karakter yang menerima kemudian melakukan proses editing atas artikel ini sehingga selesai dan dapat dimuat di Jurnal Pendidikan Karakter edisi ini. Penulis berharap semoga tulisan ini dapat bermanfaat bagi para pembaca umumnya.

\section{DAFTAR PUSTAKA}

Alghafri, A.S.R., \& Ismail, H.N. bin. 2014. "The Effects of Integrating Creative and Critical Thinking on Schools Students Thinking". International Journal of Social Science and Humanity, 4(6), 518-525.
Anindyta, P., \& Suwarjo, S. 2014. "Pengaruh Problem Based Learning terhadap Keterampilan Berpikir Kritis dan Regulasi Diri Siswa Kelas V". Jurnal Prima Edukasia, 2(2), 209-222. Retrieved from http://journal.uny.ac.id/index.php/jpe/article/view/2720.

As'ari, A.R. April 2014. “Ideas for Developing Critical Thinking at Primary School Level". Paper Presented at an International Seminar on Addressing Higher Order Thinking: Critical Thinking Issues in Primary Education, Islamic University of Muhammadiyah Makassar.

Bell, S. 2010. "Project Based Learning for

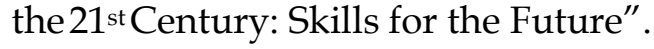
The Clearing House, 83, 39-43.

Budiharti, B. \& Jailani, J. 2014. “Keefektifan Model Pembelajaran Matematika Realistik Ditinjau dari Prestasi Belajar dan Kreativitas Siswa Sekolah Dasar". Jurnal Prima Edukasia, 2 (1), 2741. Retrieved from http://journal.uny.ac.id/index.php/jpe/article/vie $\mathrm{w} / 2642$.

Cheong, F. 2008. “Using A Problem-Based Learning Approach to Teach an Intelligent Systems Course". Jurnal of Informastion Technology Education, 7, 47-60.

Cozzola, M. 2008. Problem Based Learning and Mathematics: Possible Synergical Actions. Milano Italy. IATED: International Association of Technology, Education and Development.

El-Shaer, A. \& Gaber, H. 2014. "Impact of Problem-Based Learning on Students 
Critical Thinking Disposition, Knowledge Acquisition and Retention". Journal of Education and Practice, 5, (14), 74-85.

Hamzah, A., \& Muhlisrarini. 2014. Perencanaan dan Strategi Pembelajaran Matematika. Jakarta: Raja Grafindo Persada.

Iakovos, T. 2011. "Critical and Creative Thinking in the English Language Classroom". International Journal of Humanities and Social Science, 1, (8), 82-86.

Johnson, E. B. 2002. Contextual Teaching and Learning. Bandung: Mizan Learning Center.

Joyce, B., Weil, M., \& Calhoun, E. 2009. Models of Teaching. (Terjemahan Achmad Fawaid \& Ateilla Mirza). New Jersey: Pearson Education.

Lau, J.Y.F. 2011. An introduction to Critical Thinking and Creativity. New Jersey: Wiley.

Nitko, A. J., \& Brookhart, S. M. 2007. Educational Assassement of Student. New Jersey: Pearson Education, Inc.
Rusman. 2010. Model-model Pembelajaran: Mengembangkan Profesionalisme Guru. Jakarta: Rajawali.

Sanjaya, W. 2006. Strategi Pembelajaran Berorientasi Standar Proses Pendidikan. Jakarta: Kencana Prenada Media.

Savin-Baden, M. 2007. A Practical Guide to Problem-based Learning Online. New York: Routledge.

Tan, O. S. (Ed.). 2009. Problem-based Learning and Creativity. Singapore: Cengange Learning Asia Pte Ltd.

Widyastuti, N., \& Pujiastuti, P. 2014. "Pengaruh Pendidikan Matematika Realistik Indonesia (PMRI) terhadap Pemahaman Konsep dan Berpikir Logis Siswa". Jurnal Prima Edukasia, 2 (2), 183-193. Retrieved from http://journal.uny.ac.id/index.php/jpe/article/ view/2718/2268.

Zabit, M.N.M. 2010. “Problem-Based Learning on Students Critical Thinking Skills in Teaching Business Education in Malaysia: A Literature Review". American Journal of Business Education, 3 (6), 19-32. 